\title{
Measuring transportation at a human scale: An intercept survey approach to capture pedestrian activity
}

\author{
Robert James Schneider ${ }^{a}$ \\ University of Wisconsin-Milwaukee
}

\begin{abstract}
Pedestrian travel data are critical for measuring and analyzing sustainable transportation systems. However, traditional household travel surveys and analysis methods often ignore secondary modes, such as walking from a street parking space to a store entrance or walking from a bus stop to home. New data collection and analysis techniques are needed, especially in areas where walking is common. This paper describes an intercept survey methodology used to measure retail pharmacy customer travel to, from, and within 20 shopping districts in the San Francisco Bay Area. Of the 1003 respondents, 959 (96 percent) reported all modes of travel used from leaving home until returning home, including secondary modes. Walking was the primary travel mode on 21 percent of respondent tours, but an analysis of secondary modes found that 52 percent of tours included some walking. Pedestrian travel was particularly common within shopping districts, accounting for 65 percent of all trips within 804 meters $(0.5$ miles $)$ of survey stores. Detailed walking path data from the survey showed that respondents in denser, more mixed-use shopping districts tended to walk along the main commercial street as well as other streets connecting to the core shopping area, while respondent pedestrian movements in automobile-oriented shopping districts tended to be contained within specific shopping complexes.
\end{abstract}

\section{$1 \quad$ Introduction}

"How did you travel to the store today?" This is a common way of asking survey participants to report their mode of transportation to an activity destination. Respondents might answer with the mode that they used for the longest distance since leaving home or the mode that they used for the longest distance since leaving their last activity. However, these responses leave out information about commonly used secondary modes. Secondary modes include walking one block between home and a bus stop or walking between an on-street parking space and a store entrance. These walks use public infrastructure, represent exposure to potential traffic injury, generate physical activity for travelers, and provide mobility that does not consume fossil fuel or produce tailpipe emissions. Transportation systems are multimodal, and accurate pedestrian data are essential for making informed planning and policy decisions.

Data collection methods that capture fine-grained pedestrian movements can:

- Document all travel done on complex trip chains that utilize multiple modes and involve multiple stops

- Represent the full extent of travel done by all modes, including walking, in shopping districts and other activity centers

- Quantify the amount of exposure that pedestrians have to traffic crashes to improve estimates of injury and fatality rates
The primary purpose of this paper is to present an intercept survey method for capturing detailed information about pedestrian travel to, from, and within specific shopping districts or other activity centers. Data from this survey method were used to compare respondent pedestrian travel in four different types of San Francisco Bay Area shopping districts. This paper focuses on the data collection and analysis methodology, but it also provides data for future research on why people travel by different modes to shop at the same type of store when it is located in different urban environments.

Several terms are used in this paper to describe travel by individuals. A trip is a movement between a pair of activity locations, or stops (e.g., between home and work or between a store and a park). In general, a trip does not include travel on the same property. Travel between two different stores in the same shopping complex is considered to be a trip, as long as it involves travel outside of a building. Each trip includes at least one stage. A stage represents movement using a single mode of transportation. If a person changes modes in the middle of a trip between two activity locations (e.g., changing from walking to riding the bus), he or she is changing stages of the trip. Finally, a tour (i.e., trip chain) is the set of all trips that a person makes from leaving home until returning home. These definitions are similar to those proposed to describe travel data from the National Household Travel Survey (McGuckin and Nakamoto 2004).

a rjschnei@uwm.edu 
Shopping districts also have a specific definition in this paper. Each shopping district is defined as the area within a 0.804-kilometer (0.5-mile) radius of a store where the survey was offered.

\section{Background}

Several household travel surveys have gathered data on detailed pedestrian trip stages (Metropolitan Transportation Commission 2000; Delaware Valley Regional Planning Commission 2000; Chicago Metropolitan Agency for Planning 2008). However, the intercept survey methodology presented in this paper has two potential advantages over household survey methods for capturing pedestrian travel to specific sites. First, surveying at specific activity sites makes it straightforward to collect a sufficient sample of responses describing travel to those locations. Second, field data collection allows surveyors to prompt respondents for detailed information about short walking stages. These two advantages are described below.

Intercept surveys are useful for gathering a sufficient sample of trips associated with specific activity centers. Intercept surveys can be used to gather sufficient data about travel to specific activity locations, such as shopping districts (Steiner 1998), transit hubs (Schaller 2005), and multi-use trails (Krizek et al. 2007). Household travel surveys often capture a representative sample of people in residential neighborhoods, but they may not provide sufficient data for documenting trips to, from, and within particular activity centers. For example, more than 120 respondents to the California supplement to the $2009 \mathrm{Na}-$ tional Household Travel Survey (NHTS) made a stop in the shopping district centered at the intersection of Market Street and Fourth Street in downtown San Francisco. However, fewer than 10 NHTS respondents stopped in identically sized shopping districts in five other San Francisco Bay Area communities (FHWA 2009). This sample size issue can be addressed using intercept surveys or other methods that target a large number of respondents within a particular activity center.

Intercept surveys gather travel data while it is fresh in respondents' minds. Intercept surveyors can reference specific locations in an activity center area and prompt for information about short walking stages that might be forgotten in a household telephone survey. Since participants are intercepted during their tours, they might be able to recall more short pedestrian trips than if they were responding from home at the end of the day or week. Previous studies of underreporting have typically found that between 7 percent and 35 percent of trips collected using global positioning systems (GPS) are not reported in household travel surveys (Wolf and Oliveira 2003; Bricka and Bhat 2006; Stopher et al. 2007). These studies have focused mainly on automobile rather than pedestrian trip underreporting. However, shorter trips (Stopher et al. 2007) and trips made as a part of trip chains (Bricka and Bhat 2006) are more likely to be unreported, so pedestrian trips may have particularly high rates of underreporting (Wittink 2001). This paper presents an intercept survey method and results in different shopping districts; future studies could compare the accuracy of pedestrian trips captured by this intercept survey method versus other household travel survey and GPS survey methods.

\section{$3 \quad$ Methodology}

Detailed pedestrian data were gathered from an intercept survey of retail pharmacy store customers in the San Francisco Bay Area. The sections below describe the study area, retail pharmacy store shopping district characteristics, and survey methodology.

\subsection{Study area}

The study documented the travel behavior of a sample of retail pharmacy store customers in 20 shopping districts in the San Francisco Bay Area. Five shopping districts were selected in each of Alameda, Contra Costa, San Francisco, and San Mateo counties. In addition to being stratified by county, the set of 20 shopping districts was chosen to represent a range of local environment variables, including land-use characteristics (e.g., population density, commercial property density), transportation elements (e.g., sidewalk coverage, presence of metered onstreet parking), urban design features (e.g., survey store setback from the street, tree canopy coverage), and crime data. The shopping districts included many commercial establishments, such as retail stores, banks, post offices, gas stations, and movie theaters, but they also included a range of other land uses, including industrial, government, and residential properties.

Retail pharmacy stores were chosen for the survey because many customers would have the option of walking, bicycling, or taking transit to and from the store and using a variety of modes to travel within the shopping district. Grocery stores were not chosen because people shopping for groceries often need to carry multiple bags, which tends to favor driving to the store and between locations within the shopping district. Survey stores were selected from the same national retail pharmacy chain to control for individual store and brand preferences.

\subsection{Shopping district classification}

To compare pedestrian activity in different urban environments, the 20 shopping districts were classified into general categories using farthest neighbor cluster analysis. This analysis 


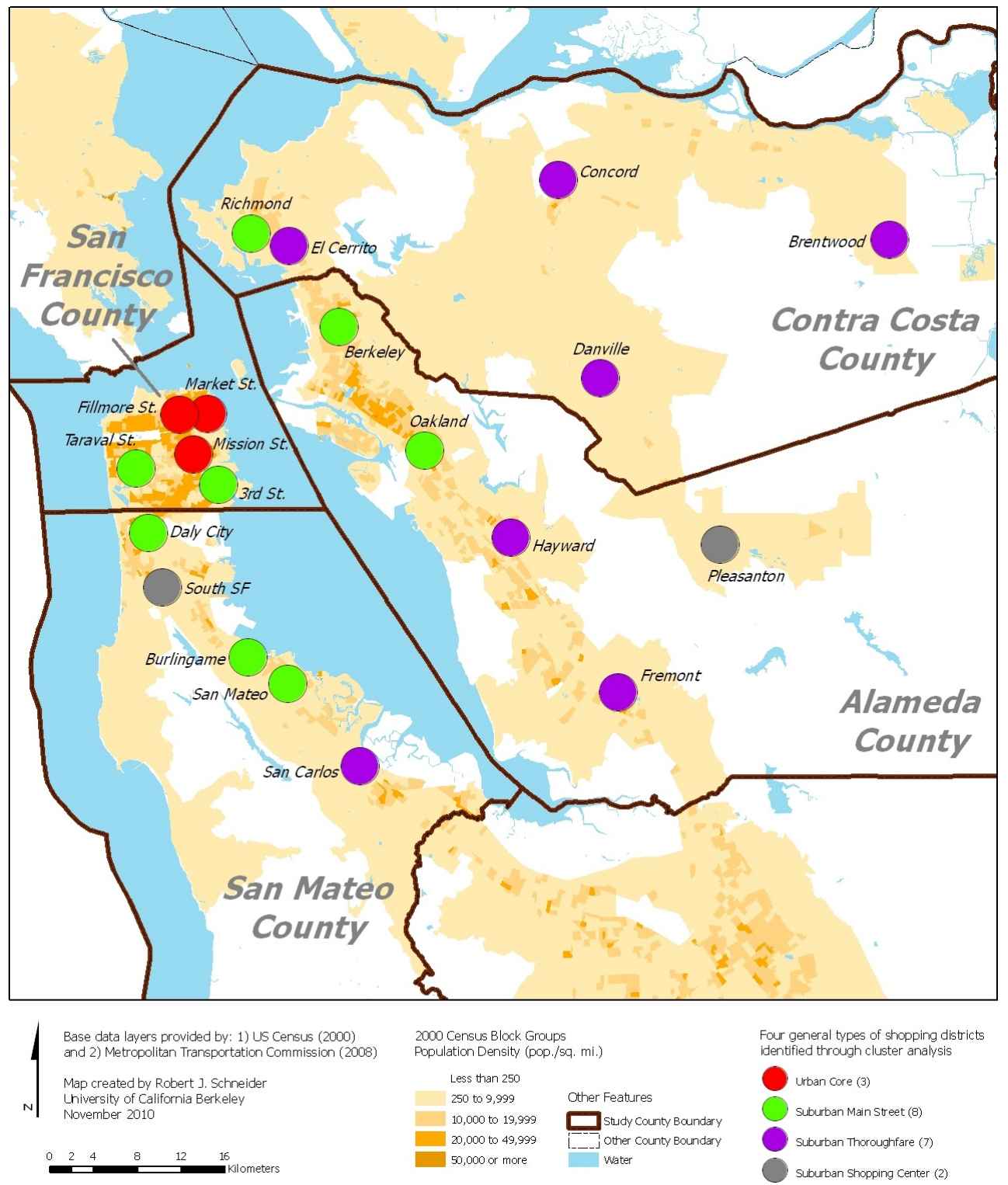

Figure 1: Twenty San Francisco Bay Area shopping districts with retail pharmacy store study sites; four types of shopping districts are identified through cluster analysis. 
was based on six built environment variables. Three variables described the shopping district area within 0.804 kilometers (0.5 miles) of the store (number of residents, number of jobs, and sidewalk coverage along multilane roadways), and three variables described the roadway corridor adjacent to the study store (average number of through-lanes along the roadway, average number of major driveway crossings per mile along the roadway, and number of spaces in the store parking lot). Differences between categories of shopping districts were identified by comparing the squared Euclidian distance with the value of each variable for each district. More detailed information about the cluster analysis is provided elsewhere (Schneider 2011).

Four categories of shopping districts were identified: 1) urban core, 2) suburban main street, 3) suburban thoroughfare, and 4) suburban shopping center (Figure 1 and Table 1).

- Urban core shopping districts had high residential and employment density and extensive sidewalk coverage. The main commercial roadway corridor in these shopping districts had short building setbacks, metered on-street parking, minimal off-street parking, two to four general-purpose through-lanes, and few nonresidential driveways. Commercial retail properties lined the roadway along the length of the corridor.

- Suburban main street shopping districts had moderate residential and employment density and extensive sidewalk coverage. The main commercial roadway corridor had mostly small commercial stores with short building setbacks, on-street parking (some metered), minimal off-street parking, and two to four throughlanes. Commercial retail properties lined the roadway along the length of the corridor.

- Suburban thoroughfare shopping districts had low residential and employment density and moderate sidewalk coverage. The main commercial roadway corridor was a high-speed, high-volume multilane street with commercial properties that were generally set back from the sidewalk behind moderate-sized parking lots. It had minimal on-street parking. Commercial retail properties lined the roadway along the length of the corridor.

- Suburban shopping center districts had low residential and employment density and moderate sidewalk coverage. The survey store was in a shopping complex with extensive off-street parking and tended to be separated from surrounding areas by high-speed, highvolume, multilane streets. The main commercial roadway corridor had minimal on-street parking. Beyond the shopping area, the corridor had few commercial retail properties.

\subsection{Intercept survey}

The intercept survey gathered travel behavior data from retail pharmacy store customers between August 29, 2009, and December 9, 2009. A total of 4585 customers were invited to participate in the survey, and 1003 (22 percent) took the survey. Surveys were distributed relatively evenly between each of the 20 stores (between 45 and 56 customers were surveyed at each store).

\section{Survey instrument}

The survey instrument was a single $22 \mathrm{x} 28$ centimeter $(8.5 \mathrm{x}$ 11 inch) sheet of paper with questions on the front side (Figure 2a) and a simple street map of the area within a 3.22-kilometer (2-mile) radius of the survey store on the back side (Figure $2 b$ ). The survey was designed to be completed in three minutes for someone who was making a simple tour. However, the average survey time was estimated to be five minutes (surveys were typically lengthened by multi-stop tours and additional comments provided by participants). Initially, the survey was designed to exclude people living more than two miles from the survey store in an attempt to ensure that most tour locations could be located on the map. This initial screening question was attempted on the first survey day, but it was determined to disrupt the flow of the survey. It was essential to engage participants in the survey mode choice questions immediately to generate interest in the topic.

\section{Survey distribution}

Approximately half of the surveys at each site were given on weekday afternoons between 4 p.m. and 6 p.m. Fridays were excluded because they were expected to have substantially different travel patterns than other weekdays. The remaining surveys at each site were given on Saturdays between 11 a.m. and 5 p.m. All surveys were administered during daylight and fair weather conditions. Temperatures during survey periods ranged from $10^{\circ} \mathrm{C}\left(50^{\circ} \mathrm{F}\right)$ to $29^{\circ} \mathrm{C}\left(85^{\circ} \mathrm{F}\right)$. Surveys were not offered when it was raining or when the previous day's forecast predicted more than a 50 percent chance of rain.

Three people administered surveys throughout the study period, including the lead researcher and two Spanish-speaking assistants. The surveyors stood 3 to 6 meters (10 to 20 feet) outside of the store exit. Customers aged 18 and older were invited to participate as they exited the store. Surveyors asked questions verbally and recorded answers on the survey instrument. After each completed survey, the next customer who exited the store was asked to participate. Some customers shopped in a group. Only one member of each group (the first adult) was 
Table 1: Types of shopping districts identified through cluster analysis.

\begin{tabular}{|c|c|c|c|c|c|c|}
\hline 1. Urban Core & & & riables Used in & Cluster Analysi & & \\
\hline Store Site & \begin{tabular}{r|} 
Residential \\
population within \\
0.5 miles $^{2}$ \\
\end{tabular} & $\begin{array}{r}\text { Jobs within } \\
0.5 \text { miles }^{2}\end{array}$ & 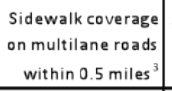 & $\begin{array}{r}\text { Average commercial } \\
\text { street number of } \\
\text { lanes }^{4}\end{array}$ & $\begin{array}{r}\text { Commercial street } \\
\text { driveway crossings } \\
\text { per mile }\end{array}$ & $\begin{array}{l}\text { Automobile parking } \\
\text { spaces at the store }\end{array}$ \\
\hline SF-Market St. & 22100 & 145200 & $100 \%$ & 4.00 & 0.00 & 0 \\
\hline SF-Fillmore St. & 24000 & 14600 & $100 \%$ & 2.00 & 0.00 & 10 \\
\hline SF-Mission St. & 32200 & 7600 & $100 \%$ & 4.00 & 0.00 & 0 \\
\hline Cluster Average & 26100 & 55800 & $100 \%$ & 3.33 & 0.00 & 3 \\
\hline
\end{tabular}

\begin{tabular}{|c|c|c|c|c|c|c|}
\hline 2. Suburban Main Street & & & riables Used in & Cluster Analysi & & \\
\hline Store Site & \begin{tabular}{r|}
$\begin{array}{r}\text { Residential } \\
\text { population within } \\
0.5 \text { miles }^{1}\end{array}$ \\
\end{tabular} & $\begin{array}{r}\text { Jobs within } \\
0.5 \text { miles }^{2}\end{array}$ & 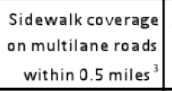 & $\begin{array}{r}\text { Average commercial } \\
\text { street number of } \\
\text { lanes }\end{array}$ & $\begin{array}{r}\begin{array}{r}\text { Commercial street } \\
\text { driveway crossings } \\
\text { per mile }\end{array} \\
\end{array}$ & $\begin{array}{l}\text { Automobile parking } \\
\text { spaces at the store }\end{array}$ \\
\hline Berkeley & 12200 & 6300 & $100 \%$ & 2.91 & 34.60 & 37 \\
\hline Oakland & 12500 & 1600 & $89 \%$ & 4.00 & 32.88 & 51 \\
\hline Richmond & 10900 & 3200 & $95 \%$ & 2.78 & 1.93 & 310 \\
\hline SF-Taraval St. & 12700 & 2100 & $98 \%$ & 4.00 & 2.01 & 0 \\
\hline SF-Third St. & 12700 & 3400 & $96 \%$ & 4.00 & 7.99 & 44 \\
\hline Daly City & 12000 & 2400 & $81 \%$ & 4.00 & 21.81 & 78 \\
\hline Burlingame & 4400 & 4400 & $77 \%$ & 2.77 & 26.06 & 20 \\
\hline San Mateo & 9600 & 6300 & $100 \%$ & 2.21 & 23.91 & 60 \\
\hline Cluster Average & 10900 & 3700 & $92 \%$ & 3.33 & 18.90 & 75 \\
\hline
\end{tabular}

\begin{tabular}{|c|c|c|c|c|c|c|}
\hline 3. Suburban Thoroughfare & \multicolumn{6}{|c|}{ Variables Used in Cluster Analysis } \\
\hline Store Site & $\begin{array}{r}\text { Residential } \\
\text { population within } \\
0.5 \text { miles } \\
\end{array}$ & $\begin{array}{r}\text { Jobs within } \\
0.5 \text { miles }^{2}\end{array}$ & $\begin{array}{l}\text { Sidewalk coverage } \\
\text { on multilane roads } \\
\text { within } 0.5 \text { miles }^{3}\end{array}$ & $\begin{array}{r}\text { Average commercial } \\
\text { street number of } \\
\text { lanes }\end{array}$ & $\begin{array}{r}\text { Commercial street } \\
\text { driveway cross ings } \\
\text { per mile }\end{array}$ & $\begin{array}{l}\text { Automobile parking } \\
\text { spaces at the store }\end{array}$ \\
\hline Hayward & 6200 & 1700 & $87 \%$ & 5.72 & 72.12 & 44 \\
\hline Fremont & 6500 & 4200 & $97 \%$ & 6.00 & 23.65 & 197 \\
\hline Danville & 1600 & 600 & $92 \%$ & 4.00 & 46.06 & 290 \\
\hline Brentwood & 1700 & 200 & $80 \%$ & 4.00 & 14.25 & 193 \\
\hline Concord & 4300 & 11600 & $97 \%$ & 5.78 & 38.09 & 59 \\
\hline El Cerrito & 6400 & 2200 & $100 \%$ & 4.28 & 58.07 & 250 \\
\hline San Carlos & 4900 & 4200 & $74 \%$ & 5.00 & 32.14 & 85 \\
\hline Cluster Average & 4500 & 3500 & $90 \%$ & 4.97 & 40.63 & 160 \\
\hline
\end{tabular}

\begin{tabular}{|c|c|c|c|c|c|c|}
\hline 4. Suburban Shopping Center & & & riables Used in & Cluster Analysi & & \\
\hline Store Site & $\begin{array}{r}\text { Residential } \\
\text { population within } \\
0.5 \text { miles }^{1} \\
\end{array}$ & $\begin{array}{r}\text { Jobs within } \\
0.5 \text { miles }^{2}\end{array}$ & $\begin{array}{r}\text { Sidewalk coverage } \\
\text { on multilane roads } \\
\text { within } 0.5 \text { miles }^{3} \\
\end{array}$ & $\begin{array}{r}\text { Average commercial } \\
\text { street number of } \\
\text { lanes }\end{array}$ & $\begin{array}{r}\text { Commercial street } \\
\text { driveway cross ings } \\
\text { per mile }\end{array}$ & $\begin{array}{l}\text { Automobile parking } \\
\text { spaces at the store }\end{array}$ \\
\hline Pleasanton & 3800 & 1200 & $84 \%$ & 4.87 & 18.49 & 442 \\
\hline S. San Francisco & 8600 & 800 & $54 \%$ & 4.53 & 15.31 & 420 \\
\hline Cluster Average & 6200 & 1000 & $69 \%$ & 4.70 & 16.90 & 431 \\
\hline
\end{tabular}

\begin{tabular}{|l|r|r|r|r|r|r|}
\hline Overall & \multicolumn{5}{|c|}{ Variables Used in Cluster Analysis } \\
\hline & $\begin{array}{r}\text { Residential } \\
\text { population within } \\
0.5 \text { miles }^{1}\end{array}$ & $\begin{array}{r}\text { Jobs within } \\
0.5 \text { miles }^{2}\end{array}$ & $\begin{array}{r}\text { Sidewalk coverage } \\
\text { on multilane roads } \\
\text { within } 0.5 \text { miles }\end{array}$ & $\begin{array}{r}\text { Average commercial } \\
\text { street number of } \\
\text { lanes }\end{array}$ & $\begin{array}{r}\text { Commercial street } \\
\text { driveway cross ings } \\
\text { per mile }^{5}\end{array}$ & $\begin{array}{r}\text { Automobile parking } \\
\text { spaces at the store }^{6}\end{array}$ \\
\hline Overall Average & $\mathbf{1 0 5 0 0}$ & $\mathbf{1 1 2 0 0}$ & $\mathbf{9 0} \%$ & $\mathbf{4 . 0 4}$ & $\mathbf{2 3 . 4 7}$ & $\mathbf{1 3 0}$ \\
\hline
\end{tabular}

Note: 1 mile $=1.61 \mathrm{~km} ; 0.5$ miles $=804 \mathrm{~m}$

1) The calculation of population only included portions of census blockgroups that were within the $804 \mathrm{~m}$ (0.5 mile) radius of the store. Source: US Census (2000).

2) The calculation if jobs only included portions of traffic analysis zones that were within the $804 \mathrm{~m}$ ( 0.5 mile) radius of the store. Source: San Francisco Bay Area Metropolitan Transportation Commission traffic analysis zones (2005).

3) The sidewalk coverage calculation assumes that complete coverage is continuous sidewalks on both sides of the street. Therefore, if a street has sidewalks on both sides, it has $100 \%$ sidewalk coverage. If a street has a complete sidewalk on one side, but no sidewalk on the other, it has 50\% coverage. Source: Google Earth \& Bing Maps aerial photographs (2007-2009).

4) Travel lanes include all general purpose through-lanes in both directions. The number of through-lanes does not include left- or right-turn lanes, two-way center turn lanes, bicycle lanes, shoulders, or other auxilary lanes. In addition, it does not include lanes that end within the segment. Source: Google Earth \& Bing Maps aerial photographs (2007-2009).

5) Major driveway crossings include all active non-residential and more-than-10-unit residential property driveways. Source: Google Earth \& Bing Maps aerial photographs (2007-2009)

6) Number of parking spaces in the store parking lot (includes shared parking with other stores in the same shopping complex). Source: Google Earth \& Bing Maps aerial photographs (2007-2009) 


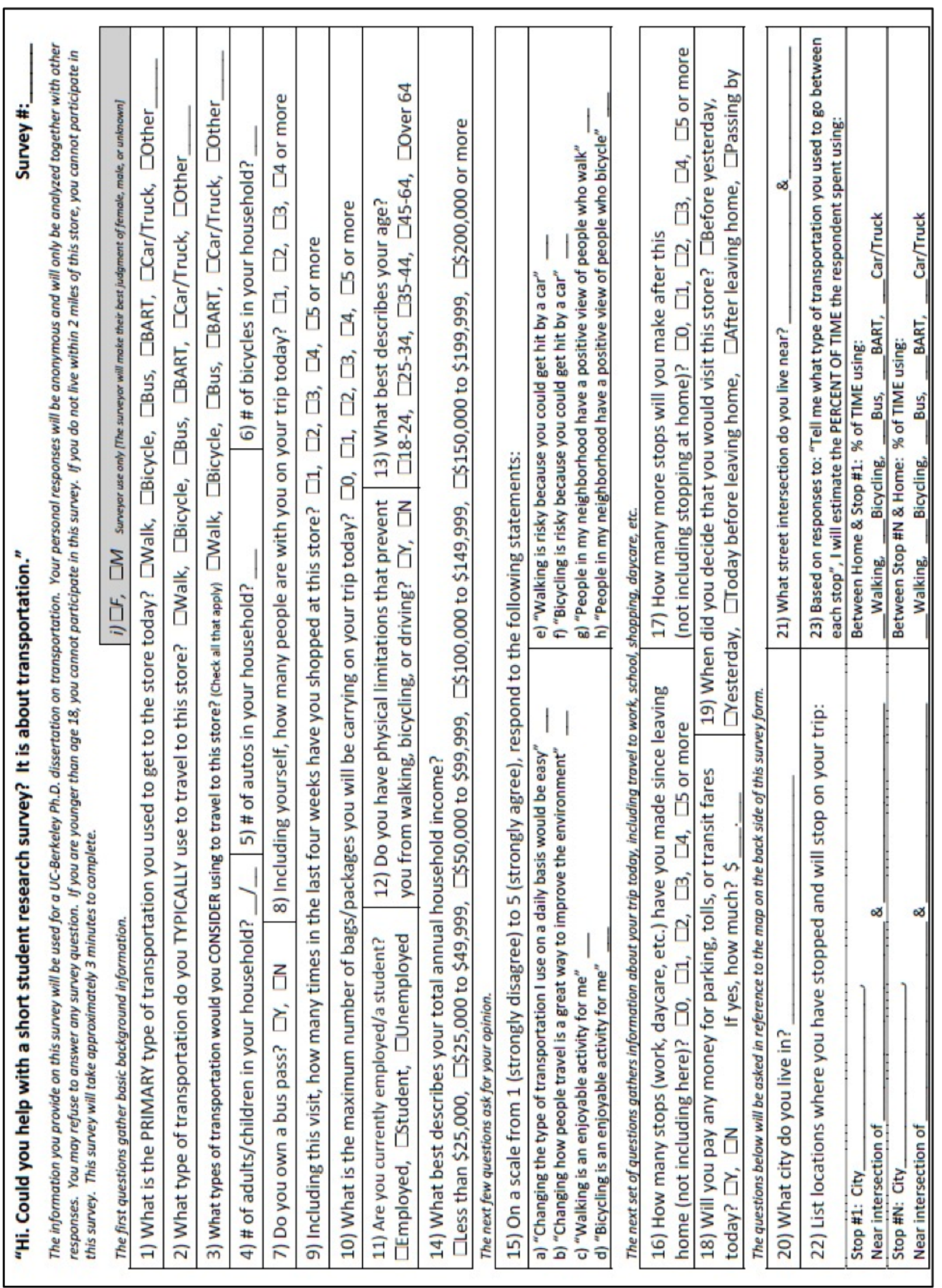

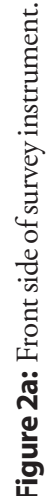


The map below shows all streets within two miles of this store. Please mark an " $\mathrm{X}$ " on all locations that you have made stops at in this area (including the intersection near your home). Also draw a line along the roadways and pathways you have used to travel between these lacations.

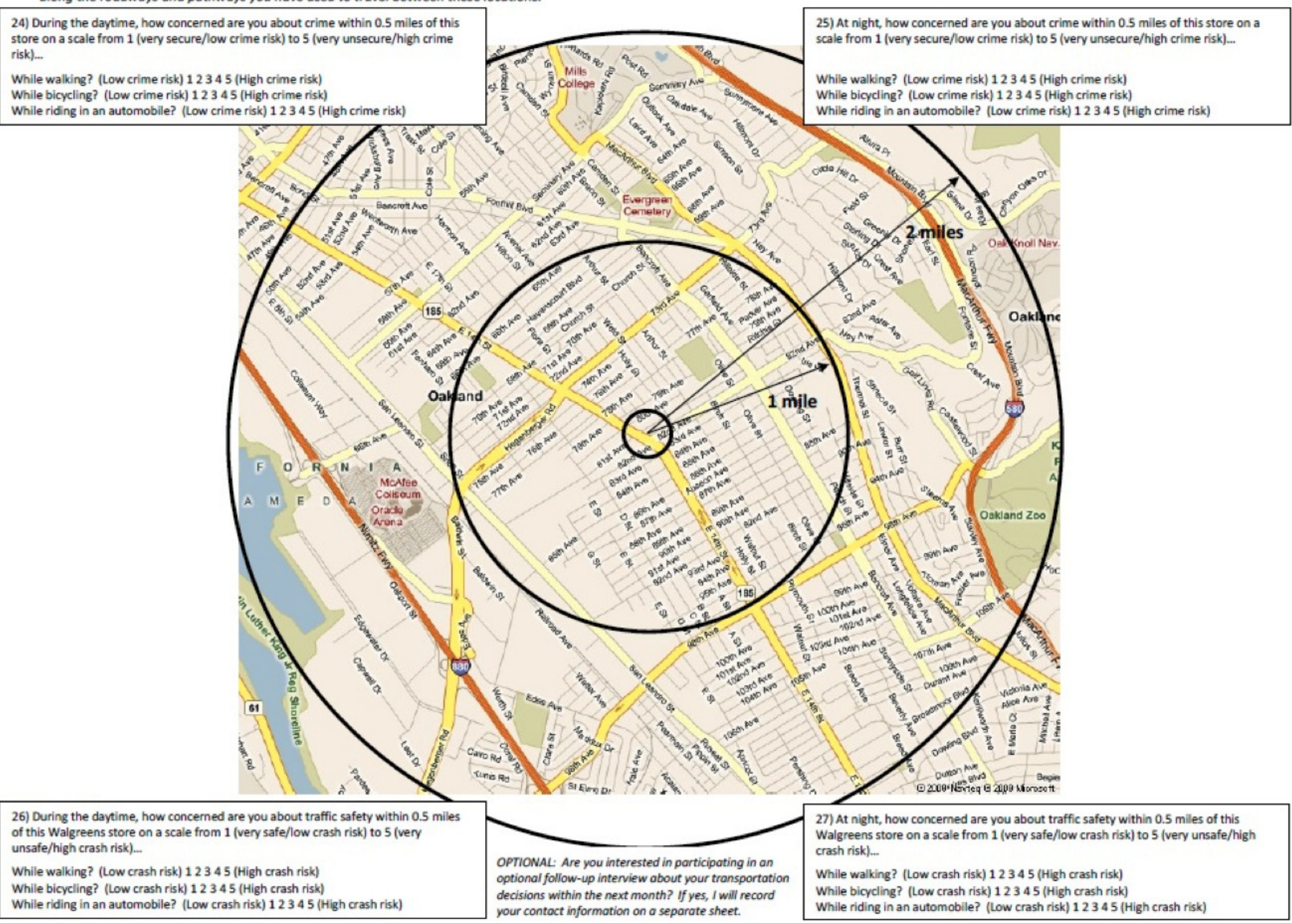

Figure 2b: Back side of survey instrument for the Oakland survey site. 
Table 2: Survey response rates and participant characteristics by type of shopping district.

\begin{tabular}{|c|c|c|c|c|c|c|c|c|c|c|}
\hline \multirow[b]{2}{*}{$\begin{array}{l}\text { Survey and Participant } \\
\text { Characteristics }^{1}\end{array}$} & \multicolumn{8}{|c|}{ Type of Shopping District } & \multirow[b]{2}{*}{ Total } & \multirow[b]{2}{*}{$\%$} \\
\hline & Urban Core & $\%$ & $\begin{array}{r}\text { Suburban } \\
\text { Main Street }\end{array}$ & $\%$ & $\begin{array}{r}\text { Suburban } \\
\text { Thoroughfare }\end{array}$ & $\%$ & $\begin{array}{r}\text { Suburban } \\
\text { Shopping Center }\end{array}$ & $\%$ & & \\
\hline Total Surveys & 161 & & 407 & & 338 & & 97 & & 1003 & \\
\hline Total Refusals $\mathrm{s}^{2,3}$ & 686 & & 1453 & & 1079 & & 364 & & 3582 & \\
\hline Response Rate $^{4}$ & $19.0 \%$ & & $21.9 \%$ & & $23.9 \%$ & & $21.0 \%$ & & $21.9 \%$ & \\
\hline \multicolumn{11}{|l|}{ Day of Week } \\
\hline Weekday & 78 & $48.4 \%$ & 199 & $48.9 \%$ & 175 & $51.8 \%$ & 47 & $48.5 \%$ & 499 & $49.8 \%$ \\
\hline Saturday & 83 & $51.6 \%$ & 208 & $51.1 \%$ & 163 & $48.2 \%$ & 50 & $51.5 \%$ & 504 & $50.2 \%$ \\
\hline \multicolumn{11}{|l|}{ Gender } \\
\hline Female & 92 & $57.1 \%$ & 246 & $60.4 \%$ & 201 & $59.6 \%$ & 55 & $57.3 \%$ & 594 & $59.3 \%$ \\
\hline Male & 69 & $42.9 \%$ & 161 & $39.6 \%$ & 136 & $40.4 \%$ & 41 & $42.7 \%$ & 407 & $40.7 \%$ \\
\hline \multicolumn{11}{|l|}{ Age Group } \\
\hline $18-34$ & 65 & $40.4 \%$ & 136 & $33.4 \%$ & 91 & $27.1 \%$ & 17 & $17.5 \%$ & 309 & $30.9 \%$ \\
\hline $35-64$ & 79 & \begin{tabular}{|l|}
$49.1 \%$ \\
\end{tabular} & 226 & $55.5 \%$ & 198 & $58.9 \%$ & 62 & $63.9 \%$ & 565 & $56.4 \%$ \\
\hline 65 and Older & 17 & \begin{tabular}{|l|}
$10.6 \%$ \\
\end{tabular} & 45 & $11.1 \%$ & 47 & $14.0 \%$ & 18 & $18.6 \%$ & 127 & $12.7 \%$ \\
\hline \multicolumn{11}{|l|}{ GroupSize } \\
\hline 1 & 121 & $75.2 \%$ & 288 & $71.1 \%$ & 245 & $73.1 \%$ & 79 & $81.4 \%$ & 733 & $73.4 \%$ \\
\hline 2 & 32 & $19.9 \%$ & 80 & $19.8 \%$ & 64 & $19.1 \%$ & 14 & $14.4 \%$ & 190 & $19.0 \%$ \\
\hline 3 & 7 & $4.3 \%$ & 25 & $6.2 \%$ & 18 & $5.4 \%$ & 2 & $2.1 \%$ & 52 & $5.2 \%$ \\
\hline $4+$ & 1 & $0.6 \%$ & 12 & $3.0 \%$ & 8 & $2.4 \%$ & 2 & $2.1 \%$ & 23 & $2.3 \%$ \\
\hline \multicolumn{11}{|c|}{ Language used for Survey } \\
\hline English & 139 & $86.3 \%$ & 359 & $88.2 \%$ & 317 & $93.8 \%$ & 96 & $99.0 \%$ & 911 & $90.8 \%$ \\
\hline Spanish & 22 & $13.7 \%$ & 48 & $11.8 \%$ & 21 & $6.2 \%$ & 1 & $1.0 \%$ & 92 & $9.2 \%$ \\
\hline
\end{tabular}

1) The total number of surveys in particular categories may not sum to 1,003 because of non-response to certain questions.

2) Overall, the survey respondents were similar to people who were invited to take the survey but declined to participate:

- $59 \%$ of respondents were female; $41 \%$ of respondents were male ( $56 \%$ of non-respondents were female; $44 \%$ of non-respondents were male).

- $31 \%$ of respondents were between ages 18 and $34,56 \%$ were between 35 and 64 , and $13 \%$ were 65 or older (30\% of non-respondents were estimated to be between the ages 18 and 34, 56\% were estimated to be between 35 and 64, and 14\% were estimated to be 65 or older).

- $73 \%$ of respondents were traveling alone, $19 \%$ were traveling in two-person groups, $5 \%$ were traveling in three-person groups, and $2 \%$ were traveling in four-or-more person groups ( $78 \%$ of non-respondents were estimated to be traveling alone, $16 \%$ were estimated to be traveling in two-person groups, $4 \%$ were estimated to be traveling in three-person groups, and $1 \%$ were estimated to be traveling in four-or-more person groups). It is likely that some customers who declined to participate were traveling with other group members who were waiting in a car, shopping in a nearby store, or exiting the store at a different time. Therefore, the actual group size for some customers who did not participate could have been larger than recorded.

- $50 \%$ of surveys were on weekdays, $50 \%$ of surveys were on Saturdays ( $51 \%$ of non-responses were on weekdays; $49 \%$ of non-responses were on Saturdays).

3) Characteristics of people who exited the store while surveys were being administered to other customers were not recorded.

4) Response rate was calculated as Number of surveys/Total number of people invited to participate in survey. 
invited to participate. Response rates and respondent characteristics are presented in Table 2.

Insights into non-response were gained over three months of surveying. Reasons for not participating in the survey included lack of time, childcare responsibilities, language barriers, distractions from cell phones and other communication devices, distrust of surveyors, and illness. These reasons may indicate certain types of non-response bias. For example, illness may have prevented some people who declined to participate from walking or traveling long distances. Non-participants who felt rushed, such as parents with childcare responsibilities, may have been more likely to choose a mode that had a higher travel speed, such as an automobile, rather than walking.

\section{Geocoding survey responses}

Of the 1003 participants, 959 (96 percent) provided tour data suitable for geocoding in GIS. The 959 tours that could be geocoded included a total of 4069 trips between 5028 home and activity stop locations (since home was recorded as the first and last stop of a tour, the number of stops was one more than the number of trips for each respondent). Tour stops were entered in a point database, and tour stages were entered in a line segment database (605 of the trips included more than one stage; each stage was represented by its own line so that different modes could be analyzed separately). Of the 5028 stop locations, 3976 (79 percent) were within the $3.22-\mathrm{km}$ (2-mile) radius of the survey store. These stops were marked on the survey map and geocoded to within approximately one-half block, within 30 to 80 meters ( 0.02 to 0.05 miles) of the actual stop location. For stops made outside of this radius, respondents listed the name of the city or neighborhood where they stopped. These locations were geocoded to a general location within the neighborhood or community. In addition, actual travel routes were approximated because it was not feasible to ask respondents to list specific roadways used on their tour within the short survey timeframe. Therefore, longer stage distances in the geographic information system (GIS) line database tended to be less accurate than shorter stage distances.

Several respondents reported the locations of stops they made before the store, but they did not know where they were going afterward. After prompting, these participants reported locations where they thought they might go. In addition, some respondents could have added unanticipated stops to their tour before returning home. It was not possible to know how many people revised their travel plans after completing the survey. Responses describing when participants decided to go to the survey store provided some insight into unplanned stops: 24 percent did not decide until after they left home, and 15 per- cent decided when they were passing by the store. Therefore, it was relatively common for people to make unplanned stops on a tour. This highlights a challenge of relying on self-reported travel behavior, especially for anticipated travel.

\subsection{Capturing detailed pedestrian travel data}

Specific aspects of the survey distribution method and survey instrument were tailored to capture detailed pedestrian travel data. These aspects are discussed below.

\section{Build trust and engagement in the topic}

Survey respondents may be more willing to provide detailed information such as short-distance pedestrian travel when they trust the surveyor, do not feel intimidated by the survey process, and are engaged in the survey topic. In addition to using standard confidentiality and consent procedures, the surveyors asked questions verbally and recorded responses on the survey form to build rapport with the participants and speed the survey process. This also allowed participants to ask clarifying questions about particular parts of the survey, which was likely to help them decide on answers more quickly and improve the accuracy of responses. Verbal questions and responses also avoided possible embarrassment for participants who might have had difficulty reading questions or writing answers.

The front side of the survey included questions that could be completed relatively quickly (Figure 2a). Surveyors oriented the clipboard so that the participants could see their answers being recorded, which built trust that their responses were documented correctly and showed that they were making steady progress through the questions. Some participants could have been intimidated by the map on the back of the survey (Figure $2 b$ ), so it was not revealed until they completed all of the questions on the front. This allowed participants to become engaged in the survey before they were asked to provide detailed information about walking on their tour. Only $22(2.2$ percent) of the participants who began the survey quit before completing the map exercise on the back, indicating a high level of engagement in the survey.

\section{Prepare respondents to provide detailed walking information}

Mode choice information was the central focus of the survey. Therefore, the following questions were asked first:

- "What is the PRIMARY type of transportation you used to get to the store today?" If participants mentioned more than one mode, the surveyor clarified that this was the mode used for the longest distance 
on their tour.

- "What type of transportation do you TYPICALLY use to travel to this store?"

- "What types of transportation do you CONSIDER using to travel to this store?"

Possible responses to these questions included "walk," "bicycle," "bus," "BART" (Bay Area Rapid Transit), "car/ truck," or "other." While these initial questions focused on the primary mode used on the respondent's tour rather than secondary modes, the list of possible responses put respondents in the frame of mind to think about transportation from a multimodal perspective. Even if they had not walked to the store, they would recognize that walking was included in this transportation survey.

\section{Map stop locations to provide a framework for recording modes used between stops}

Surveyors asked participants to identify the locations of their homes and all stops they made on their tours on the back of the survey. While the survey initially specified that surveyors should mark an "X" on all stop locations, the surveyors quickly changed to numbering the stop locations in the order they were visited on the respondent's tour.

After locating all stops on the map, respondents were asked to report all modes of transportation that they used on trips between each stop. If an automobile was used for any stage within a trip, respondents were asked if they parked in a parking lot, in a driveway, or on the street directly in front of their stop location. If not, the distance or number of blocks that they walked between the parking space and each activity location was recorded. If transit was used, respondents reported how far they walked to and from each transit stop (walking within a transit station or transit-station parking lot was not recorded). Surveyors took detailed notes on the map to indicate transitions between modal stages.

Mapping respondent tour stops and travel modes was also useful for improving the accuracy of the initial questions on the survey about the respondent's primary mode of transportation. Responses to this question were compared with actual primary travel modes calculated from geocoded tour data. This comparison showed that the Question 1 response and geocoded tour data differed for 72 (7.5 percent) of the 959 respondents. Most of the incorrect responses to Question 1 were due to respondents reporting walking as their primary mode when they had either used transit or an automobile for the longest distance on their tour. These respondents could have confused the walking that they had done from their last activity stop, bus stop, or parking space with their overall tour mode. Some re- spondents could have also thought that the mode they used for the greatest travel time was their primary mode. This suggests that future applications of Question 1 should define primary travel mode more clearly.

\section{$4 \quad$ Results}

The intercept survey method quantified key differences in respondent pedestrian travel by urban environment and illustrated geographic patterns of fine-grained walking movements near survey stores.

\subsection{Primary tour mode used by respondents}

Travel mode data are often summarized by the type of transportation used for the longest distance on a specific tour (i.e., primary tour mode). The most common primary tour mode for the 959 respondents was automobile (67 percent), followed by walking ( 21 percent), transit (10 percent), and bicycle ( 2 percent). There were notable differences in primary tour mode by shopping district. Urban respondents tended to walk and use transit more than their suburban counterparts (Figure 3). Walking was the primary mode used by 51 percent of participants surveyed in urban core, 24 percent in suburban main street, 9 percent in suburban thoroughfare, and 5 percent in suburban shopping center shopping districts. Analysis of variance showed that the pedestrian mode shares for the higherdensity, more mixed-use urban core and suburban main street shopping districts were significantly different from the other suburban shopping districts $(\alpha=0.01)$.

Many conventional travel survey analyses stop after providing this information. However, the intercept survey included sufficient data to analyze trips and fine-grained walking movements made by participants on their full tours and within each shopping district.

\subsection{Secondary trip modes used by respondents}

The intercept survey captured information about each stage of respondent tours. When secondary modes were considered, 52 percent of survey respondents reported walking for at least one stage on their tours. Respondent tours included 4069 individual trips, and 605 (15 percent) of these trips used more than one mode of travel. The most common secondary trip mode used by respondents was walking, representing 95 percent of secondary modes. Other secondary modes included driving (to or from transit) and bicycling (to or from transit). Multiple modes were used more often on trips to, from, and within urban core (23 percent) and suburban main street (19 percent) shopping districts than suburban shopping center 




Figure 3: Primary tour mode share for survey respondents by shopping district. 


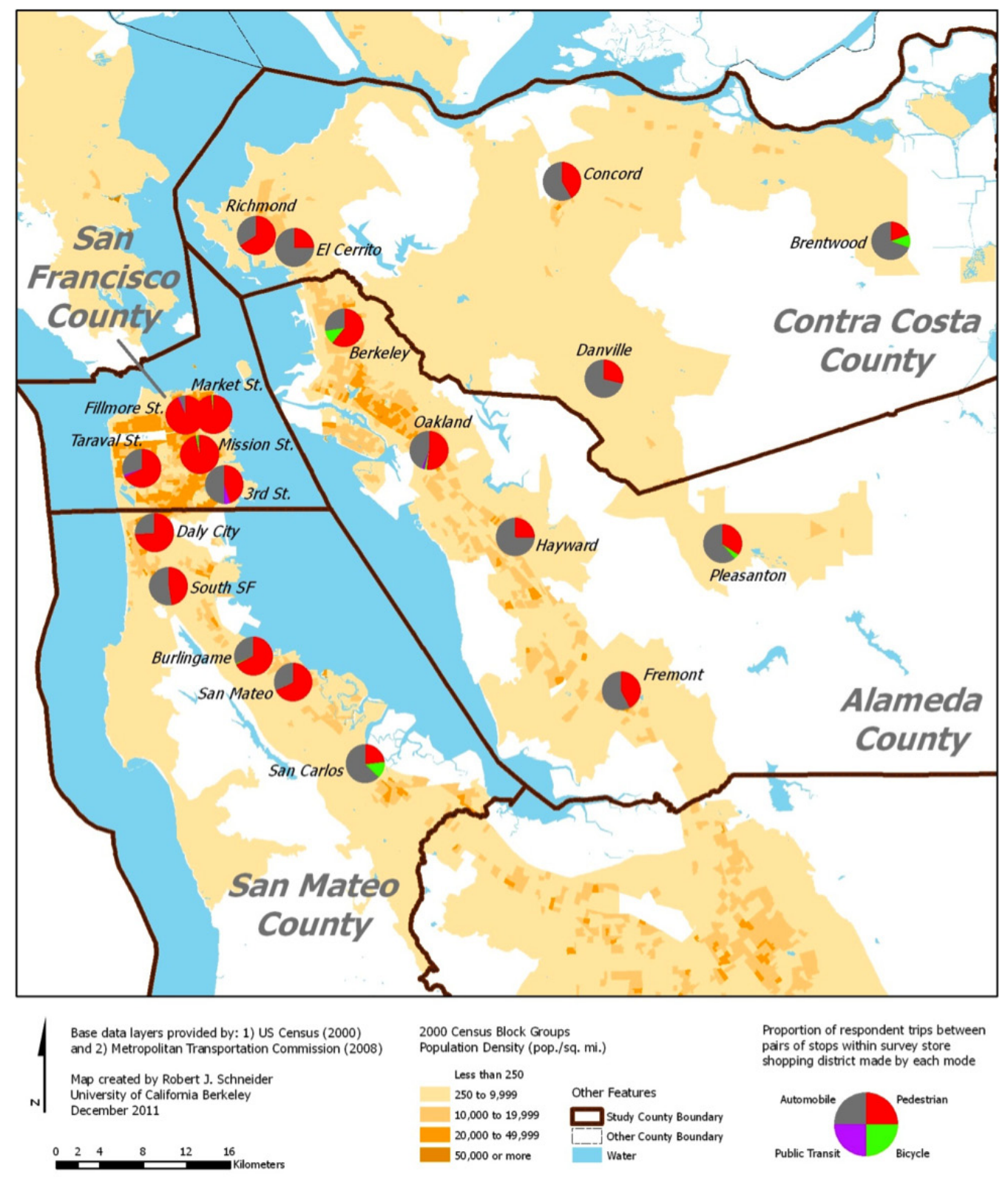

Figure 4: Mode share for respondent trips within shopping districts. 

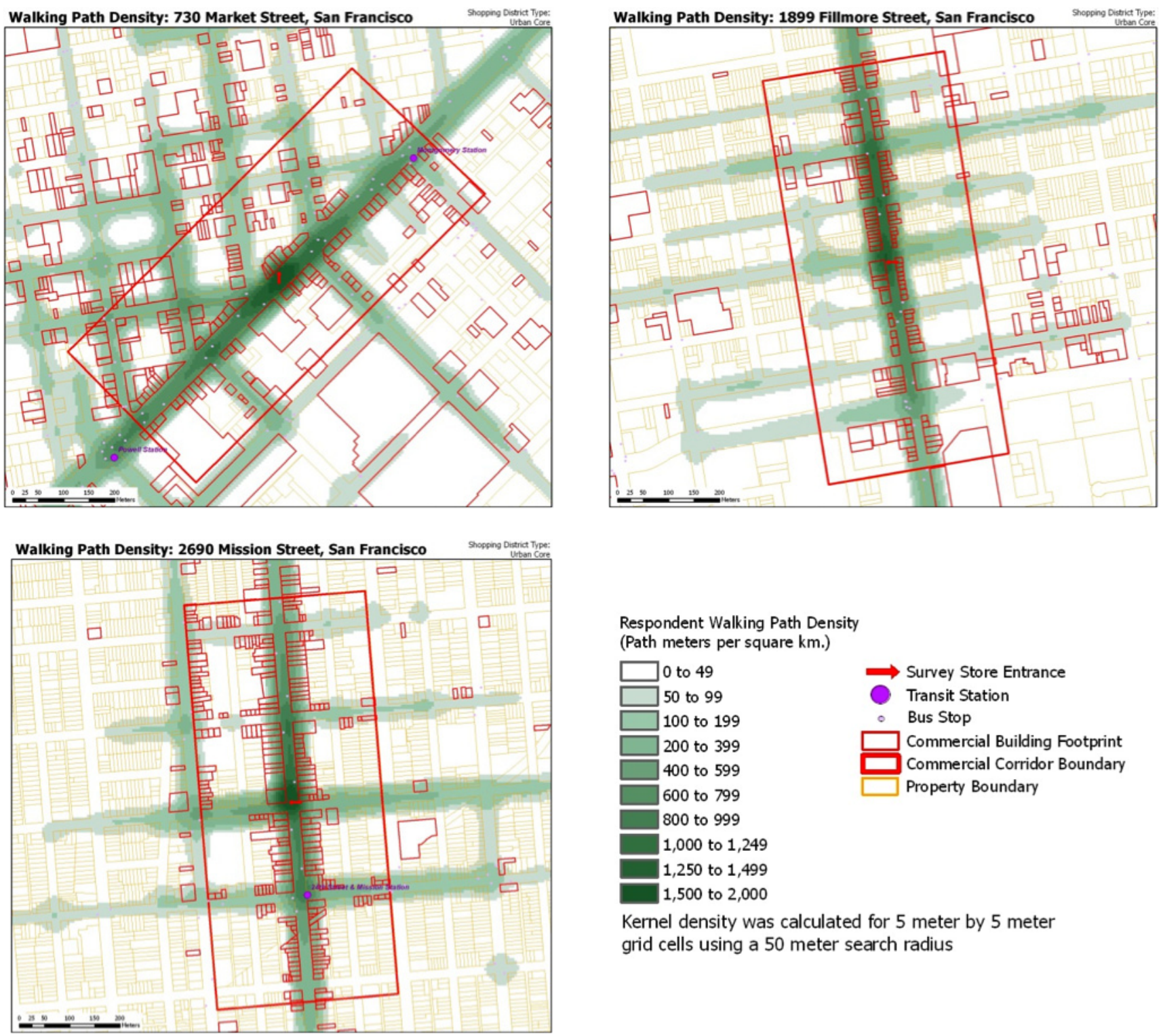

Respondent Walking Path Density (Path meters per square $\mathrm{km}$.)

\begin{tabular}{|c|}
\hline 0 to 49 \\
\hline 50 to 99 \\
\hline 100 to 199 \\
\hline 200 to 399 \\
\hline 400 to 599 \\
\hline 600 to 799 \\
\hline 800 to 999 \\
\hline 1,000 to 1,249 \\
\hline 1,250 to 1,499 \\
\hline 1,500 to 2,000 \\
\hline
\end{tabular}

Kernel density was calculated for 5 meter by 5 meter grid cells using a 50 meter search radius

Figure 5: Respondent walking path density in urban core shopping districts. 

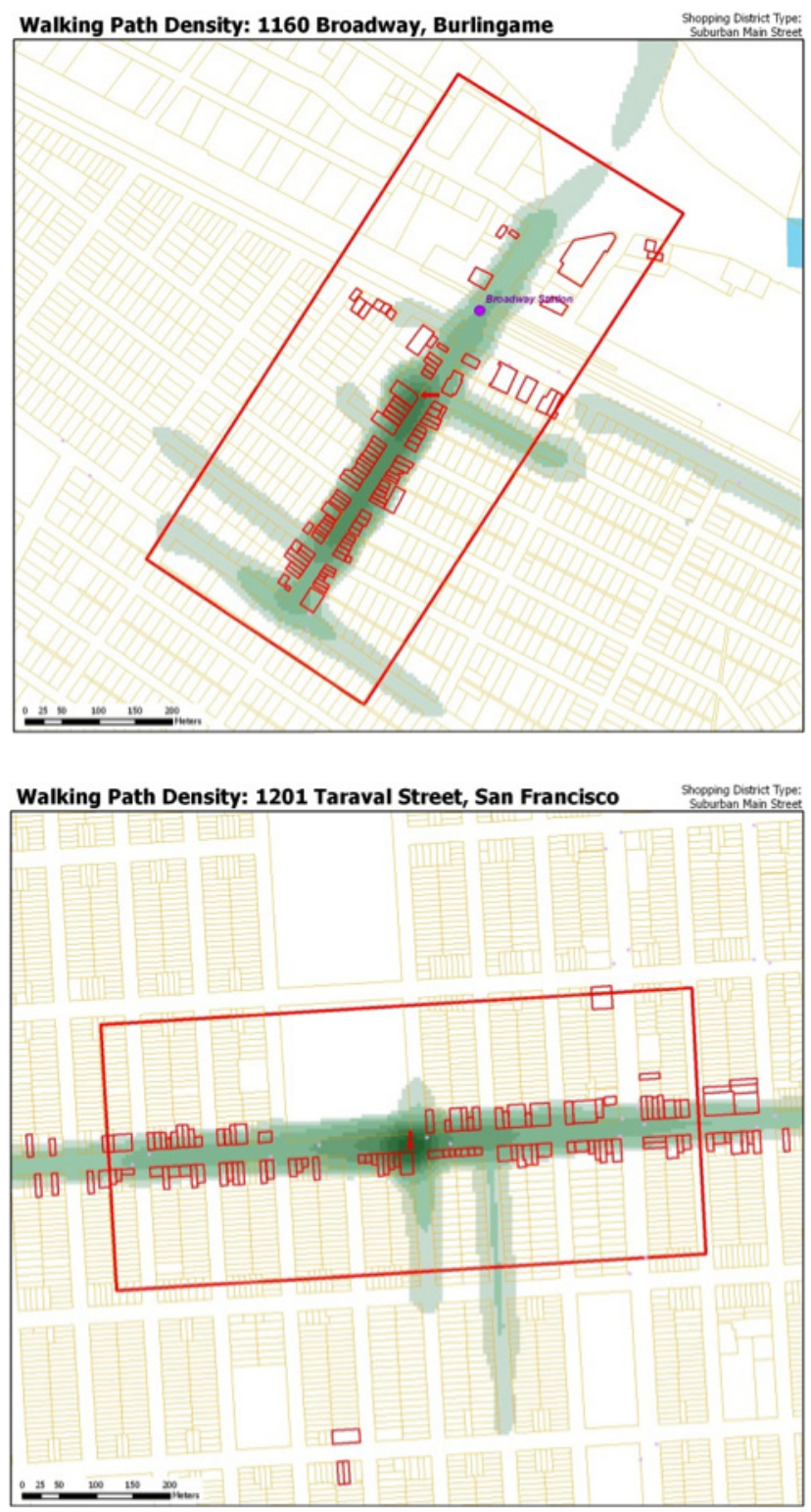

Respondent Walking Path Density (Path meters per square $\mathrm{km}$.)

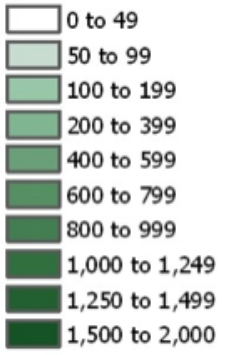

Kernel density was calculated for 5 meter by 5 meter grid cells using a 50 meter search radius

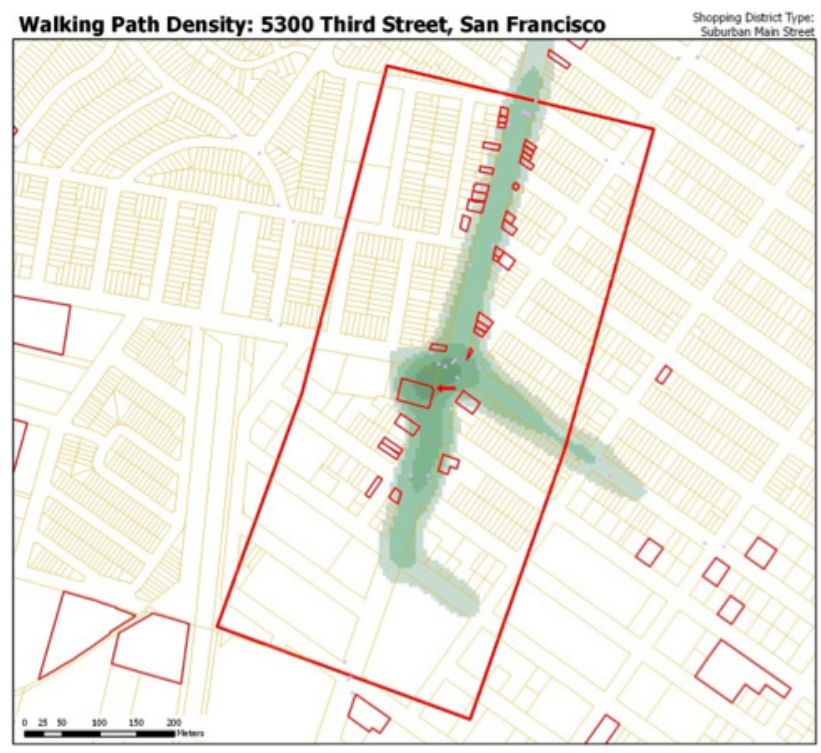

Walking Path Density: 1150 Macdonald Avenue, Richmond

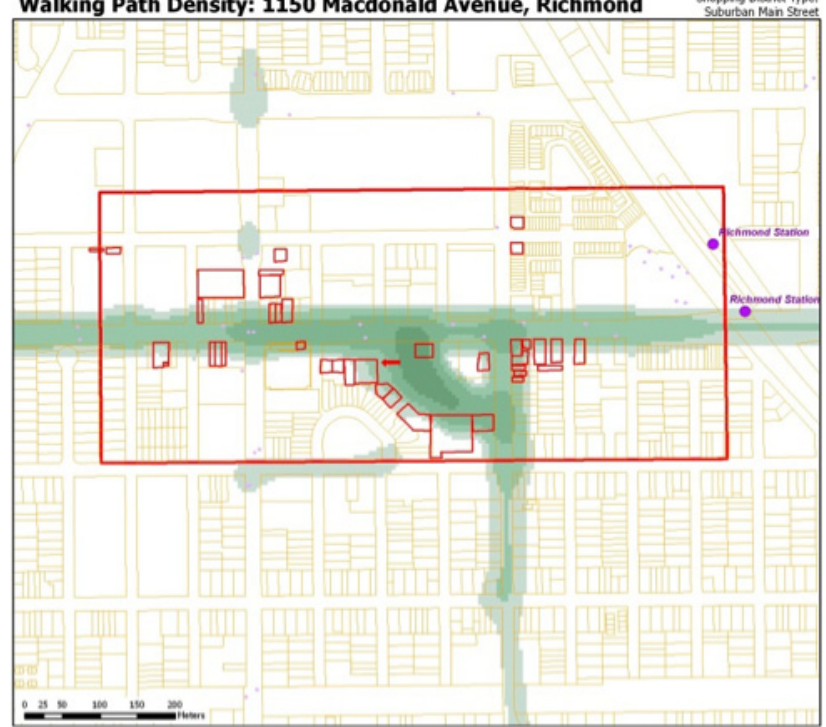

Figure 6: Respondent walking path density in selected suburban main street shopping districts. 

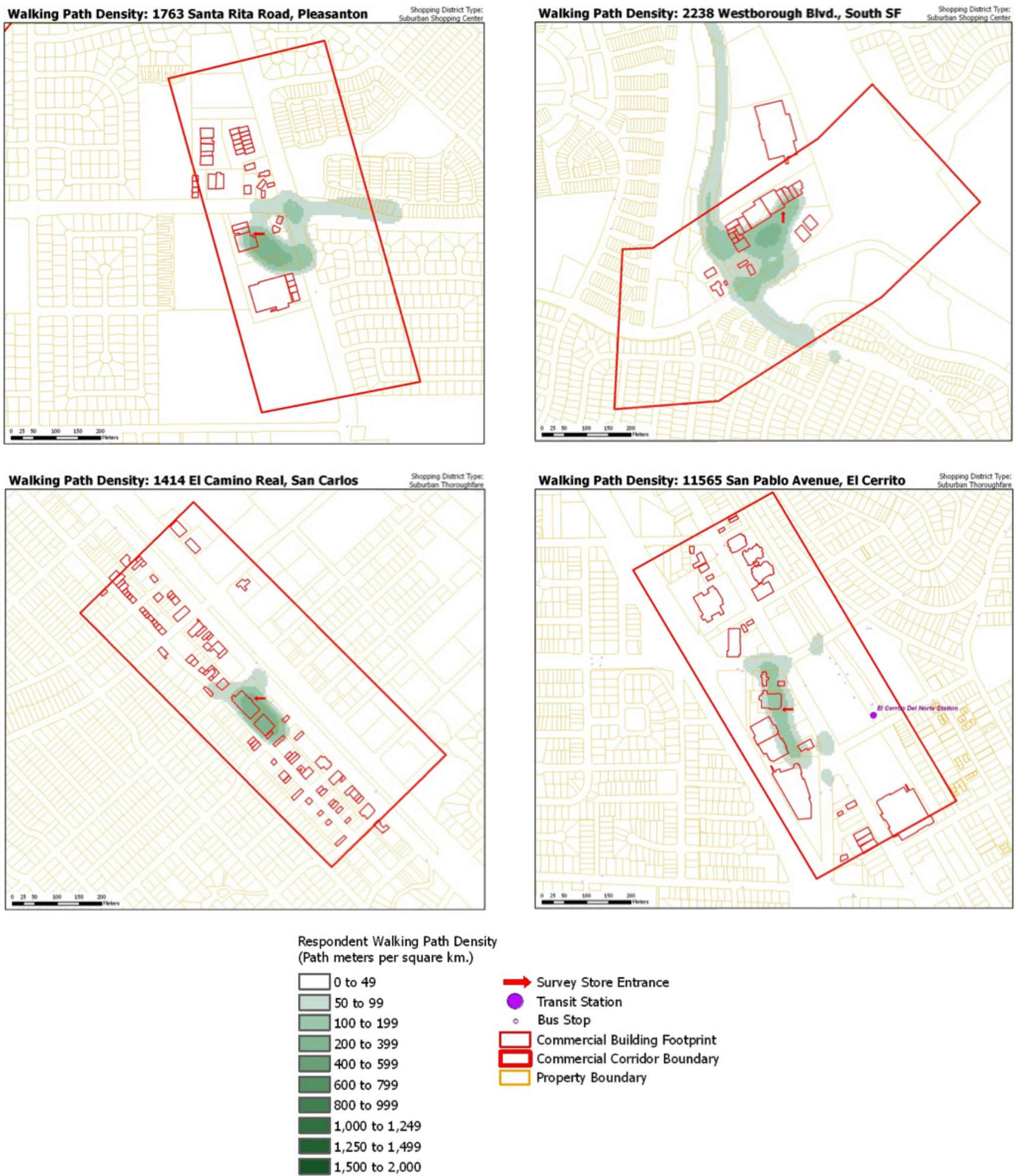

Kernel density was calculated for 5 meter by 5 meter grid cells using a 50 meter search radius

Figure 7: Respondent walking path density in selected suburban thoroughfare and suburban shopping center shopping districts. 
(9 percent) and suburban thoroughfare (7 percent) shopping districts (analysis of variance showed that this difference was significant for $\alpha=0.05$ ). It is important to collect secondary trip mode data to document all pedestrian travel, especially in dense, mixed-use areas.

\subsection{Mode used by respondents on trips within shop- ping districts}

Walking was used as the primary mode for 65 percent of the 1382 respondent trips between pairs of stops within shopping districts. Respondent walking was most common within higher-density, more mixed-use shopping districts (Figure 4). A majority of trips within urban core shopping districts (96 percent) and suburban main street shopping districts (63 percent) were made by walking. While walking was less common among respondents in low-density suburban shopping districts than the urban core and suburban main street shopping districts (analysis of variance showed that this difference was significant for $a$ $=0.01$ ), these automobile-oriented shopping districts still had pedestrian activity. Thirty percent of respondent trips starting and ending within suburban thoroughfare shopping districts and 40 percent of respondent trips within suburban shopping center districts were made by walking.

\subsection{Pedestrian path density}

Survey data on short trips and secondary modes of transportation were useful for representing pedestrian movements geographically. Line density maps show where concentrations of respondent pedestrian activity occurred. Survey respondents in urban core shopping districts tended to walk along the main commercial street as well as other streets connecting to the core shopping area (Figure 5). Respondent pedestrian patterns in suburban main street shopping districts tended to concentrate along the length of the main shopping street (Figure 6). In contrast, many pedestrian movements in suburban thoroughfare and suburban shopping center shopping districts were contained within specific shopping complex areas, suggesting that most respondents traveled to the district by automobile and some walked between stores (Figure 7).

\section{Considerations and future research}

The intercept survey captured the travel patterns of a specific group of participants at retail pharmacy stores during specific survey time periods. It was not intended to represent the travel patterns of a community or region as a whole. Future surveys could be done in employment centers, residential neighborhoods, or recreational areas to capture more complete pedes- trian travel data in other types of locations. While the San Francisco Bay Area provided a range of urban and suburban environments for capturing detailed pedestrian data, it would be useful to do a similar study in a different region.

The survey was designed to capture all walking respondents did on public streets and between stores in shopping complexes. Many people reported these walking movements, but it is possible that others did not mention these short walking stages because they had already forgotten them, had survey fatigue, or did not anticipate that they would be walking from parking or bus stops later in their tours. Therefore, it is likely that the survey still underreported pedestrian travel.

Global positioning systems (GPS) techniques may be able to collect similar complete tour data (Stopher et al. 2010). Several researchers have used GPS to document bicycle travel routes and speeds (Dill and Gliebe 2008; Hood et al. 2011). Data from GPS units can be reviewed by survey participants during follow-up interviews to correct preliminary route and mode information (Dill and Gliebe 2008). Challenges of using this type of approach include: 1) participants being aware of carrying the devices and possibly modifying their travel behavior to conform with social norms or research expectations; 2) representative sampling (e.g., if GPS units are used, only a certain type of person may be willing to travel with a device; if tracks from mobile devices are used, the analysis will only represent people who own these devices); 3) locating transition points between modes such as walking, bicycling, and public transit accurately; and 4) missing route data due to loss of contact with satellites, devices being turned off or running out of batteries, or other recording errors. In addition, study participants would typically be equipped with GPS units at home or work, so it would be challenging to obtain a sufficient amount of survey data to describe travel movements near specific activity locations.

\section{Conclusion}

As agencies seek to improve multimodal travel data, intercept surveys have the potential to capture detailed information about walking. These surveys can be especially useful for understanding the prevalence of walking within specific geographic areas, such as shopping districts and activity centers. The intercept survey of retail pharmacy store customers in 20 San Francisco Bay Area shopping districts showed that walking was often used as a secondary mode after driving or taking transit for much of the distance between activity stops. It also showed that respondent pedestrian travel was common within shopping districts, especially those with higher densities and a greater mix of land uses. 


\section{References}

Bricka, S. and C.R. Bhat. 2006. Comparative analysis of global positioning system-based and travel survey-based data. Transportation Research Record 1972: 9-20.

Chicago Metropolitan Agency for Planning. 2008. Chicago Regional Household Travel Inventory Data User's Manual. Chicago: Chicago Metropolitan Agency for Planning.

Delaware Valley Regional Planning Commission. 2000. Transportation for the 21st Century Household Travel Survey: Travel Survey Results for the DVRPC Region. Philadelphia: Delaware Valley Regional Planning Commission.

Dill, J. and J. Gliebe. 2008. Understanding and measuring bicycling behavior: A focus on travel time and route choice. Oregon Transportation Research and Education Consortium, OTREC-RR-08-03.

http://pdxscholar.library.pdx.edu/cgi/viewcontent. cgi?article=1027\&context=usp_fac. (Accessed September 6, 2013.)

Hood, J., E. Sall, and B. Charlton. 2011. A GPS-based bicycle route choice model for San Francisco, California. Transportation Letters: The International Journal of Transportation Research 3(1): 63-75.

Krizek, K., A. El-Geneidy, and K. Thompson. 2007. A detailed analysis of how an urban trail system affects cyclists' travel. Transportation 34(5): 611-624.

McGuckin, N. and Y. Nakamoto. 2004. Trips, chains, and tours - using an operational definition. Presented at the National Household Travel Survey Conference, Washington, DC.

http://onlinepubs.trb.org/onlinepubs/archive/conferences/ nhts/McGuckin.pdf. (Accessed March 9, 2012.)

Metropolitan Transportation Commission. 2000. Bay Area Travel Survey. Oakland, California: Metropolitan Transportation Commission.

Schaller, B. 2005. On-board and intercept transit survey techniques. Transit Cooperative Research Program Synthesis 63, Transportation Research Board, Washington, DC.

Schneider, R.J. 2011. Understanding sustainable transportation choices: Shifting routine automobile travel to walking and bicycling. http://www.uctc.net/research/UCTC-DISS-2011-01.pdf. (Accessed March 9, 2012.)

Steiner, R. 1998. Trip generation and parking requirements in traditional shopping districts. Transportation Research Record 1617: 28-37.

Stopher, P., C. FitzGerald, and M. Xu. 2007. Assessing the accuracy of the Sydney Household Travel Survey with GPS. Transportation 34(6): 723-741.
Stopher, P., C. Prasad, and J. Zhang. 2010. Can GPS replace conventional travel surveys? Some findings. Australasian Transport Research Forum 2010 Proceedings, Canberra, Australia.

http://www.patrec.org/web_docs/atrf/papers/2010/1940_034\%20-\%20Stopher\%20Prasad\%20 Zhang.pdf. (Accessed March 9, 2012.)

U.S. Department of Transportation, Federal Highway Administration. 2009. National Household Travel Survey. http://nhts.ornl.gov. (Accessed July 2011.)

Wittink, R. 2001. Promotion of mobility and safety of vulnerable road users. SWOV Institute for Road Safety Research, Leidschendam, The Netherlands. http://www.swov.nl/rapport/d-2001-03.pdf. (Accessed March 9, 2012.)

Wolf, J., M. Olivera, and M. Thompson. 2003. Impact of underreporting on mileage and travel time estimates. Transportation Research Record 1854: 189-198. 